3. Pro $B$, Advani R, Brice $P$, Bartlett NL, Rosenblatt JD, Illidge $T$, Matous J, Ramchandren $R$, Fanale $M$, Connors JM, Yang $Y$, Sievers EL, Kennedy DA, Shustov A. Brentuximab vedotin (SGN-35) in patients with relapsed or refractory systemic anaplastic large-cell lymphoma: results of a phase II study. J Clin Oncol 2012;30:2190-2196.

4. Onaka T, Kitagawa T, Kawakami C, Yonezawa A. Improvement of cutaneous anaplastic large cell lymphoma by brentuximab vedotin monotherapy. Turk J Hematol 2018;35:135-136.

5. Horwitz $S$, O'Connor OA, Pro B, Illidge $T$, Fanale M, Advani R, Bartlett NL, Christensen JH, Morschhauser F, Domingo-Domenech E, Rossi G, Kim WS, Feldman T, Lennard A, Belada D, Illés Á, Tobinai $K$, Tsukasaki $K$, Yeh SP, Shustov A, Hüttmann A, Savage KJ, Yuen S, Iyer S, Zinzani PL, Hua Z,
Little M, Rao S, Woolery J, Manley T, Trümper L; ECHELON-2 Study Group. Brentuximab vedotin with chemotherapy for CD30-positive peripheral T-cell lymphoma (ECHELON-2): a global, double-blind, randomised, phase 3 trial. Lancet 2019;393:229-240.

6. Prince HM, Kim YH, Horwitz SM, Dummer R, Scarisbrick J, Quaglino P, Zinzani PL, Wolter P, Sanches JA, Ortiz-Romero PL, Akilov OE, Geskin L, Trotman J, Taylor K, Dalle S, Weichenthal M, Walewski J, Fisher D, Dréno B, Stadler R, Feldman T, Kuzel TM, Wang Y, Palanca-Wessels MC, Zagadailov E, Trepicchio WL, Zhang W, Lin HM, Liu Y, Huebner D, Little M, Whittaker S, Duvic M; ALCANZA Study Group. Brentuximab vedotin or physician's choice in CD30positive cutaneous T-cell lymphoma (ALCANZA): an international, openlabel, randomised, phase 3, multicentre trial. Lancet 2017;390:555-566.

๑Copyright 2021 by Turkish Society of Hematology

Turkish Journal of Hematology, Published by Galenos Publishing House

\title{
A Promising New Therapy of Oral Ixazomib Without Rituximab for Waldenstrom Macroglobulinemia
}

\author{
Waldenström Makroglobulinemisinde Rituksimab İçermeyen Yeni Umut Verici Oral \\ Iksazomib Tedavisi
}

\author{
(D) Wanlu Ma1, (D) Jiawei Zhao², (D) Lu Zhang³ \\ 1 Peking Union Medical College Hospital, Chinese Academy of Medical Sciences and Peking Union Medical College, Department of Endocrinology, \\ Beijing, China \\ 2 Peking Union Medical College Hospital, Chinese Academy of Medical Sciences and Peking Union Medical College, Department of Rheumatology, \\ Beijing, China \\ ${ }^{3}$ Peking Union Medical College Hospital, Chinese Academy of Medical Sciences and Peking Union Medical College, Department of Hematology, \\ Beijing, China
}

\section{To the Editor,}

A 73-year-old woman was admitted with complaints of low fever, fatigue, shortness of breath, and edema of the lower extremities. Hemoglobin $(\mathrm{Hb})$ and platelets (PLTs) were 76-93 g/L (normal range: $110-160 \mathrm{~g} / \mathrm{L}$ ) and $75-103 \times 109 / \mathrm{L}(100-300 \times 109 / \mathrm{L})$, respectively. Serum protein electrophoresis indicated that $M$ protein and immunoglobulin $\mathrm{M}$ were elevated to $8.6 \mathrm{~g} / \mathrm{L}$ and $11.9 \mathrm{~g} / \mathrm{L}(0.4-2.3 \mathrm{~g} / \mathrm{L})$. Blood immunofixation electrophoresis also exhibited positive immunoglobulin M (IgM)к. Computed tomography (CT) scans revealed multiple enlarged lymph nodes in the mediastinum, mesentery, neck, underarms, and groin with pericardial and pleural effusion and splenomegaly (Figures $1 \mathrm{~A}$ and $1 \mathrm{C}$ ). A bone marrow smear revealed $7.5 \%$ lymphocytic plasma cells, whose immune phenotypes were consistent with Waldenstrom macroglobulinemia (WM). Furthermore, L265P mutation in MYD88 was detected in the bone marrow and pleural effusion. Accordingly, WM was diagnosed and the RCD regimen (rituximab, dexamethasone, cyclophosphamide) was given for 2 cycles, but her PLTs quickly decreased to $15 \times 109 / \mathrm{L}$ with petechiae during the infusion of rituximab, probably due to rituximab-induced thrombocytopenia [1]. Two weeks later, PLTs gradually increased to $80 \times 10^{9} / \mathrm{L}$, but $\mathrm{Hb}$ remained at $54 \mathrm{~g} / \mathrm{L}$ and $\mathrm{M}$ protein did not decrease. A CT scan did not show any reduction of pericardial or pleural effusion. Meanwhile, a new-onset femoral neck fracture prevented her from coming to the hospital for a bortezomib-based regimen and economic status restricted her from usage of ibrutinib and ICD (ixazomib, dexamethasone, cyclophosphamide). Therefore, an oral treatment regimen was given for 1 cycle followed by 5 cycles of ID regimen (ixazomib, dexamethasone) due to neutropenia possibly induced by cyclophosphamide. Strikingly, Hb rose back to $125 \mathrm{~g} / \mathrm{L}$ and PLTs remained stable at $155 \times 109 / \mathrm{L}$. M protein fell back to $0.6 \mathrm{~g} / \mathrm{L}$. A CT scan showed normal size of multiple lymph nodes and absence of pericardial and pleural effusion (Figures 1B and 1D). The patient achieved very good partial response (VGPR) after 6 cycles of ixazomib-based regimen and remained in VGPR without maintenance for 1 year. 



Figure 1. Computed tomography (CT) scans showed multiple enlarged lymph nodes in the mediastinum and pericardial and pleural effusion before treatment (A, C). CT scan showed complete disappearance of enlarged lymph nodes and pericardial or pleural effusion after treatment $(B, D)$.

WM is a rare indolent hematologic disorder sometimes requiring treatment due to IgM-secreting lymphoplasmacytic cells in the bone marrow and other organs $[2,3]$. L265P mutation of MYD88 is present in more than $90 \%$ of cases [4]. Primary therapy options include anti-CD20 monoclonal antibodies, mainly rituximab. However, proteasome inhibitors (bortezomib, carfilzomib, ixazomib) are playing a greater role both in primary therapy and as salvage options. Bortezomib has been extensively studied and proved effective as a single agent [5], but bortezomib-associated neuropathy and toxicity limit its widespread use. Carfilzomib combined with dexamethasone has also been reported to be effective for WM [6]. However, the role of ixazomib, another oral proteasome inhibitor, has not been well illuminated. Although the IDR regimen (ixazomib, rituximab, dexamethasone) was suggested to be effective, well tolerated, and neuropathy-sparing in a prospective phase II study with $96 \%$ overall response rate in 26 symptomatic patients with WM [3], the efficacy of ixazomib-based regimens without rituximab has not been reported before. Considering that rituximab alone could be effective in WM patients (52\% overall response rate) [7] and oral ixazomib might be especially useful in the outpatient setting with less economic burden and no need for continuous treatment compared to oral ibrutinib and bortezomib, it would be helpful to delineate the efficacy of ixazomib-based oral treatment in WM patients.

Herein, we have reported the first clinical case of a patient with WM who could not tolerate rituximab due to rituximabinduced thrombocytopenia and responded well to oral ixazomib administered at home after a femoral neck fracture. Ixazomib may be considered for those not tolerating rituximab or bortezomib or those who cannot receive them for other reasons. Whether maintenance therapy adds benefits to the prognosis remains controversial [3]. Our patient remained in VGPR without maintenance therapy for a year. Further evidence concerning the benefits of ixazomib maintenance is needed.

In conclusion, our case highlights the strengths of ixazomibbased regimens without rituximab in patients with WM. As an oral proteasome inhibitor, the unique role of ixazomib in treating WM awaits further investigations. 
Keywords: Waldenstrom macroglobulinemia, Rituximabinduced thrombocytopenia, Ixazomib

Anahtar Sözcükler: Waldenström makroglobülinemisi, Rituksimab ile indüklenen trombositopeni, Iksazomib

\section{Ethics}

Informed Consent: This article does not contain any studies with human participants or animals performed by any of the authors. Informed consent for publication was obtained from the patient.

\section{Authorship Contributions}

Concept: L.Z.; Design: W.M., J.Z., L.Z.; Writing: W.M., L.Z.

Conflict of Interest: No conflict of interest was declared by the authors.

Financial Disclosure: The National Natural Science Foundation of China (81900202, for ZL) and the Fundamental Research Funds for the Central Universities (3332018036, for ZL).

\section{References}

1. Giezen TJ, Mantel-Teeuwisse AK, ten Berg MJ, Straus SM, Leufkens HG, van Solinge WW, Egberts TCG. Rituximab-induced thrombocytopenia: a cohort study. Eur J Haematol 2012;89:256-266.

2. Advani P, Paulus A, Ailawadhi S. Updates in prognostication and treatment of Waldenström's macroglobulinemia. Hematol Oncol Stem Cell Ther 2019:12:179-188.

3. Castillo JJ, Meid K, Gustine JN, Dubeau T, Severns P, Hunter ZR, Yang G, $\mathrm{Xu} \mathrm{L}$, Treon SP. Prospective clinical trial of ixazomib, dexamethasone and rituximab as primary therapy in Waldenström macroglobulinemia. Clin Cancer Res 2018;24:3247-3252.

4. Treon SP, Xu L, Yang G,Zhou Y, Liu X, Cao Y, Sheehy P, Manning RJ, Patterson CJ, Tripsas C, Arcaini L, Pinkus GS, Rodig SJ, Sohani AR, Harris NL, Laramie JM, Skifter DA, Lincoln SE, Hunter ZR. MYD88 L265P somatic mutation in Waldenstrom's macroglobulinemia. N Engl J Med 2012;367:826-833.

5. Dimopoulos MA, Anagnostopoulos A. Waldenström's macroglobulinemia. Best Pract Res Clin Haematol 2005;18:747-765.

6. Vesole DH, Richter J, Biran N, McBride L, Anand P, Huang M, Kumeli AZ, Klippel Z, Iskander K, Siegel DS. Carfilzomib as salvage therapy in Waldenstrom macroglobulinemia: a case series. Leuk Lymphoma 2018;59:259-261.

7. Gertz MA, Rue M, Blood E, Kaminer LS, Vesole DH, Greipp PR. Multicenter phase 2 trial of rituximab for Waldenström macroglobulinemia (WM): an Eastern Cooperative Oncology Group Study (E3A98). Leuk Lymphoma 2004;45:2047-2055.

๑Copyright 2021 by Turkish Society of Hematology

Turkish Journal of Hematology, Published by Galenos Publishing House

\title{
Intravascular Large B-Cell Lymphoma Within the Appendix Presenting as Acute Abdomen: A Challenging Diagnosis for Hematologists
}

\author{
Akut Abdomen ile Prezente olan Apendiksin Intravasküler Büyük B-hücreli Lenfoması: \\ Hematologlar için Zorlu bir Tanı
}

\footnotetext{
(D) Semra Cemre Atalar1, (D) Olga Meltem Akay², (D) Emre Osmanbaşoğlu², (D) Helin Masyan², (D) Orhun Çığ Taşkın³, (D) Burhan Ferhanoğlu²
}

${ }^{1}$ Koç University Faculty of Medicine, Istanbul, Turkey

${ }^{2}$ Koç University Faculty of Medicine, Department of Hematology, Istanbul, Turkey

${ }^{3}$ Koç University Faculty of Medicine, Department of Pathology, İstanbul, Turkey

\section{To the Editor,}

Intravascular large cell lymphoma (ILCL) is a rare subtype of non-Hodgkin lymphoma characterized by the proliferation of lymphoma cells within the lumen of small vessels. The clinical diagnosis of ILCL is challenging due to the absence of obvious lymphadenopathy or a detectable mass [1]. The disease is usually diagnosed postmortem or incidentally in patients with diverse signs and symptoms related to organ dysfunction caused by occlusion of blood vessels [2]. Herein, we report a case of intravascular large B-cell lymphoma (ILBCL) presenting as acute abdomen. The diagnosis was rendered following the histopathologic examination of an appendectomy specimen. To 